\title{
Directly observed treatment for tuberculosis in the State of São Paulo
}

\author{
Tratamento diretamente observado da tuberculose no Estado de São Paulo \\ Tratamiento directamente observado de la tuberculosis en el Estado de São Paulo
}

Rogério José de Azevedo Meirelles'

ORCID: 0000-0001-9208-7120

Pedro Fredemir Palha'

ORCID: 0000-0002-5220-4529

'Universidade de São Paulo. Ribeirão Preto, São Paulo, Brazil.

How to cite this article: Meirelles RJA, Palha PF. Directly observed treatment for tuberculosis in the state of São Paulo. Rev Bras Enferm. 2018;72(5):1167-72.

doi: http://dx.doi.org/10.1590/0034-7167-2017-0279

Corresponding Author:

Rogério José de Azevedo Meirelles E-mail: rjameirelles@gmail.com

Submission: 05-10-2017 Approval: 11-02-2017

\begin{abstract}
Objectives: To describe and analyze the coverage profile of directly observed treatment for tuberculosis in 59 priority municipalities in the state of São Paulo, Brazil, through the creation and comparison of groups homogenized by the number of people in each municipality from 2006 to 2012. Method: Quantitative, epidemiological and descriptive study based on the data available in the EPI-TB and the Statistica 7.0 software databases. Results: The mean and standard deviation of directly observed treatment for the 59 priority municipalities of the state of São Paulo were $77.0 \pm 24.3 \%$. The coverage of directly observed treatment increased in 34 municipalities (57.6\%) but decreased in 25 (42.4\%). Conclusion: Some municipalities could not keep the coverage reached at some point. This coverage heterogeneity should be examined in detail by searching for possible reasons in political-management, technical-operational and funding dimensions.

Descriptors: Tuberculosis; Public Health Surveillance; Primary Health Care; Health Services; Health Management.
\end{abstract}

\section{RESUMO}

Objetivo: Descrever e analisar o perfil da cobertura do Tratamento Diretamente Observado (TDO) em 59 municípios prioritários do Estado de São Paulo/Brasil, por meio da formação e comparação de subgrupos homogeneizados pelo número de habitantes/município, de 2006 a 2012. Método: Estudo quantitativo, epidemiológico e descritivo, utilizando-se o Banco EPI-TB e do Statistica 7.0. Resultados: A média e o desvio-padrão do TDO para os 59 municípios prioritários do Estado de São Paulo/Brasil foi de 77,0\% $\pm 24,3$. A cobertura do TDO foi crescente em trinta e quatro municípios $(57,6 \%)$, porém, em vinte e cinco (42,4,houve uma diminuição da porcentagem de cobertura. Conclusão: Alguns municípios não conseguiram manter a sustentabilidade da cobertura alcançada em algum momento. Essa heterogeneidade de cobertura precisa ser aprofundada, buscando as possíveis explicações nas dimensões político-gerencial, técnico-operacional e do financiamento das ações em tuberculose (TB).

Descritores: Tuberculose; Vigilância em Saúde Pública; Atenção Primária à Saúde; Serviços de Saúde; Gestão em Saúde.

\section{RESUMEN}

Objetivo: Describir y analizar el perfil de cobertura del Tratamiento Directamente Observado (TDO) en 59 municipios relevantes del Estado de São Paulo/Brasil, mediante formación y comparación de subgrupos, homogeneizados por el número de habitantes/ municipio, de 2006 a 2012. Método: Estudio cuantitativo, epidemiológico y descriptivo, utilizándose el Banco EPI-TB y el Statistica 7.0. Resultados: La media y el desvío estándar del TDO para los 59 municipios relevantes del Estado de São Paulo/Brasil fue del 77,0\% \pm 24,3 . La cobertura del TDO resultó creciente en treinta y cuatro municipios $(57,6 \%)$, aunque en veinticinco $(42,4 \%)$ hubo una disminución del porcentaje de cobertura. Conclusión: Algunos municipios no consiguieron mantener la sustentabilidad de la cobertura alcanzada en algún momento. Esta heterogeneidad de cobertura necesita profundizarse, buscando las posibles explicaciones en las dimensiones político-gerenciales, técnico-operativas y de financiamiento de acciones en TB.

Descriptores: Tuberculosis; Vigilancia en Salud Pública; Atención Primaria De Salud; Servicios de Salud; Gestión En Salud. 


\section{INTRODUCTION}

Tuberculosis (TB) has been a humanitarian, economic and public health issue in Brazil since the twentieth century ${ }^{(1)}$ and is still recognized as a neglected disease ${ }^{(2-3)}$. When TB control policies were launched in Brazil, the disease was kept under control until the mid-1980s. After this period, some factors related to public management and economic and social circumstances impaired such control ${ }^{(4-6)}$.

In Brazil, data from the Brazilian Notifiable Diseases Surveillance System (SINAN, as per its acronym in Portuguese), by means of the Brazilian Program for Tuberculosis Control of the Health Surveillance Secretariat from the Ministry of Health ${ }^{(7)}$, point to 71,123 new cases of TB in 2013, which caused the country to move up from the $19^{\text {th }}$ to the $15^{\text {th }}$ position in the list of the 22 countries with the highest disease burden. Brazil currently occupies the $22^{\text {nd }}$ position in this list when it comes to incidence, prevalence and mortality rates, and the $111^{\text {th }}$ position when it comes to incidence only. In addition, TB is the fourth more common cause of death by chronic infectious diseases in the country (4,406 people) and the leading cause of death among infectious illnesses that affect people with the acquired immunodeficiency syndrome (AIDS), caused by the human immunodeficiency virus (HIV) ${ }^{(8-10)}$.

Recently, a new era in TB treatment has begun, and the World Health Organization (WHO) ${ }^{(11)}$ redefined the priority country classification for the period from 2016 to 2020. This new grouping is made up of three lists with 30 countries, according to their epidemiological characteristics: 1) TB burden, 2) multi-drug resistant TB, and 3) TB and HIV co-infection. Some countries are in more than one set, so the list totals 48 priority countries for TB approach. Brazil was included in two of the three groups and takes the $20^{\text {th }}$ position in the TB burden rank and the $19^{\text {th }}$ position in the TB and HIV co-infection classification. It is noteworthy that the countries in the WHO list make up $87 \%$ of TB cases worldwide ${ }^{(12)}$.

Historically, the Brazilian Southeast region, encompassing the states of Espírito Santo, Minas Gerais, Rio de Janeiro and São Paulo, presents the highest TB notification rate. In 2000, 38,690 cases were notified. This number decreased to around 35,000 in 2003 and 32,820 in 2006. The numbers revealed that the state of São Paulo had the highest number of new bacilliferous TB cases (15,346 per 100,000 people). The most recent data, from 2011 and available at the TBWEB system, show that the state registered 13,480 new bacilliferous TB cases $^{(13)}$.

There have been several governmental actions to reach the goals advocated by $\mathrm{WHO}^{(11)}$. One of them is the creation of the Tuberculosis Control Program (TCP), which is part of the health services network and has been developed in a unified way, in a joint effort by federal, state and municipal spheres. The program is subject to a policy for planning actions, with well-defined technical and care standards, to guarantee aspects ranging from the distribution of free medication and other resources to preventive actions and worsening control of $\mathrm{TB}^{(9)}$.

In 1996, the Emergency Plan for Tuberculosis Control (EPTC) was released. It recommended the implementation of supervised treatment, currently named directly observed treatment (DOT), which is one of the cornerstones of the WHO strategy entitled Directly Observed Treatment Short-Course (DOTS).

Because of the increasing TB rates, DOT remains a priority toward the heal goal for at least $85 \%$ of patients. This would reduce the dropping out rates and prevent the emergence of resistant bacilli, allowing an effective TB control in the country ${ }^{(14)}$.

Despite the efforts of the EPTC to follow the guidelines of the DOTS strategy, it is necessary to consolidate the action of states and municipalities to combat TB in accordance with the national program. This means to reinforce coordination, planning, funding, supervision and evaluation activities in the three government spheres for the immediate remediation of any detected problems ${ }^{(15-18)}$.

The exposed scenario shows that studies which describe and analyze the coverage levels of DOT in different municipalities can help formulate specific health management strategies, so cultural, institutional, vocalization and technical learning diversity are known and respected, and consequently assessed regarding its efficacy.

\section{OBJECTIVE}

To analyze the DOT coverage for TB in medium and large priority municipalities in the state of São Paulo from 2006 to 2012.

\section{METHOD}

\section{Ethical aspects}

The present study used public access information, that is, data which can be used in research and knowledge transfer and which are available to researchers and citizens with no restrictions, not subject to limitations related to privacy, security or access control. The information used by the authors was processed and retrieved on the internet and produced and administered by public institutions, from census research and databases built upon aggregated information, with no possibility of individual identification, and with the consultation to scientific texts for reviewing scientific literature. Consequently, it was not necessary to submit the project proposal to a research ethics committee, in accordance with the Brazilian National Research Ethics Committee system (CEP/CONEP, as per its acronym in Portuguese) in the terms of item 5, chapter XIII, resolution 466 from December $12^{\text {th }} 2012$ of the Brazilian Health Council, about research that uses public access information, according to the law 12,527 from November $18^{\text {th }} 2011$.

\section{Study design, setting and period}

Quantitative, epidemiological and descriptive study which used information from the EPI-TB database, from the São Paulo Health Secretariat, recorded until December 2012.

\section{Population and sample}

The sample had 59 priority municipalities $(80.8 \%)$, which met the following inclusion criteria: municipalities with at least 100,000 people, an incidence coefficient higher than 47 per 100,000 people and a mortality coefficient by TB higher than 3 per 100,000 people ${ }^{(16)}$.

The municipalities were divided into five subgroups for a comparative analysis of TB control according to the population size: 
- Subgroup $A(n=22$, between 100 and 200 thousand people): Rio Claro, Araçatuba, Ferraz de Vasconcelos, Francisco Morato, Itu, Itapecerica da Serra, Pindamonhangaba, Bragança Paulista, São Caetano do Sul, Franco da Rocha, Atibaia, Araras, Cubatão, Santana de Parnaíba, Catanduva, Barretos, Guaratinguetá, Várzea Paulista, Salto, Poá, Ourinhos and Caraguatatuba.

- Subgroup $B(n=15$, between 201 and 300 thousand people): Taubaté, Limeira, Praia Grande, Suzano, Taboão da Serra, Barueri, São Carlos, Marília, Americana, Jacareí, Indaiatuba, Araraquara, Cotia, Presidente Prudente and Itapevi.

- Subgroup C ( $n=8$, between 301 and 400 thousand people): Jundiaí, Carapicuíba, Piracicaba, Bauru, São Vicente, Itaquaquecetuba, Franca and Guarujá.

- Subgroup $D(n=5$, between 401 and 500 thousand people): Mauá, São José do Rio Preto, Santos, Mogi das Cruzes and Diadema.

- Subgroup $E(n=9$, over 501 thousand people): São Paulo, Guarulhos, Campinas, São Bernardo do Campo, Santo André, Osasco, São José dos Campos, Ribeirão Preto and Sorocaba.

\section{Inclusion and exclusion criteria}

To check the percentage of DOT coverage, an instrument was designed and applied to collect the following information: year of implementation of the DOTS strategy in each of the 59 priority municipalities, population size, new cases with and without DOT in a one-year period, from 2006 to 2012. The indicator of DOT coverage was calculated through the formula:

\section{$\mathrm{C}=$ number of new cases with DOT-TB, year, municipality X 100\% total number of new cases, year, municipality}

The EPI-TB database, from the São Paulo Health Secretariat, was used to organize the information about the coverage of DOT focused on TB and the number of people living in the municipalities ${ }^{(16)}$.

\section{Result analysis and statistics}

The collected data were inserted into Excel ${ }^{\circledR} 2007$ electronic worksheets by using the double typing and checking technique to minimize possible mistakes during information transcription. Subsequently, the data were imported to the Statistica 7.0 - Statasoft ${ }^{\oplus}$ software for calculation of means and standard deviations for each municipality and subgroup and graph plotting for a descriptive analysis of the results.

\section{RESULTS}

The evolution of DOT coverage in the 22 municipalities with a population between 100 and 200 thousand people, or subgroup A, behaved as Figure 1 shows.
Among these municipalities, Ferraz de Vasconcelos, despite having a population lower than 200 thousand people $(180,326)^{(10)}$, presented a low DOT coverage from 2006 to 2012, in contrast to other municipalities within the same population group (São Caetano do Sul, Bragança Paulista, Araçatuba, and Cubatão) that exhibited a satisfactory improvement in coverage, even above the goal advocated by WHO(11). Catanduva and Várzea Paulista showed total coverage (100\%).

Taboão da Serra (264,352 people), Araraquara (222,036 people) and Presidente Prudente (218,960 people), which have similar numbers of residents, did not show the same evolution in DOT coverage. Presidente Prudente did not reach $35 \%$ of coverage, but Taubaté exceeded $97 \%$. The opposite was observed for São Carlos in comparison with Limeira, Suzano or Jacareí, which presented similar total populations and DOT coverages, as displayed in Figure 2.

Eight cities had a low DOT coverage when compared to other municipalities with similar numbers of residents $(11.6 \%$ of average coverage, with a standard deviation of $\pm 5.47 \%)$. The cities of Piracicaba (90.4\%), Itaquaquecetuba (90.5\%), Jundiaí (94.1\%), Franca (98.3\%), Guarujá (98.4\%) and São Vicente (98.7\%) had coverage percentages higher than the target established by $\mathrm{WHO}^{(11)}$. The average coverage calculated for municipalities of subgroup $C$ was $63.5 \%$, with a standard deviation of $\pm 17.7 \%$ (Figure 3 ).

The data revealed that São José do Rio Preto moved from 69.0\% of coverage in 2006 to $98.3 \%$ in 2012, which means an increase of $29.3 \%$, and that Mauá, which had a coverage of $22.0 \%$ in 2006, 
increased it to $95.8 \%$ in 2012, a growth of 73.8\%. Contrarily, Mogi das Cruzes stood out for presenting the lowest coverage among these five cities. It exhibited a DOT coverage of $9.0 \%$ in 2006 , which decreased to $4.0 \%$ in 2007 , grew to $6.0 \%$ in 2008 , to $9.0 \%$ in 2009 , reduced to $8.0 \%$ in 2010 , rose sharply in comparison with the previous years, reaching $37.5 \%$ in 2011 and kept increasing in 2012 , with a final coverage of $66.4 \%$, an evidence that the municipality is getting close to the goal of $85 \%$ advocated by $\mathrm{WHO}^{(11)}$. The average coverage in this subgroup in the past six years was $60.1 \%$, with a standard deviation of $\pm 8.1 \%$ (Figure 4 ).

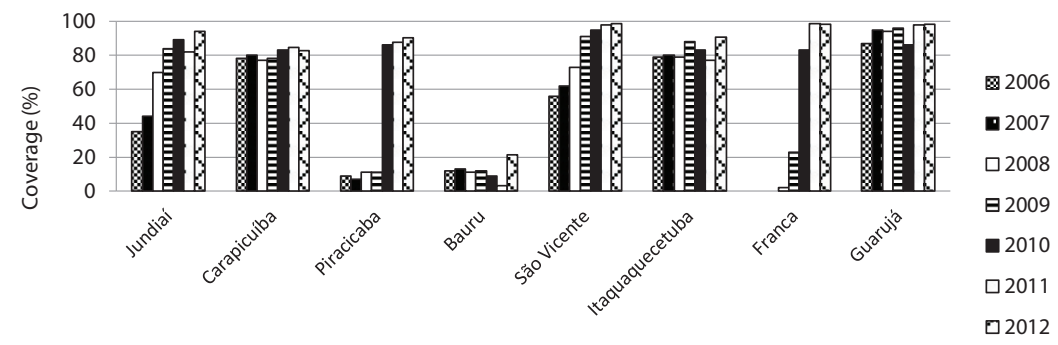

Priority municipalities with a population between 301 and 400 thousand people

Figure 3 - Evolution of Directly Observed Treatment Short-Course coverage in subgroup C from 2006 to 2012, state of São Paulo, Brazil

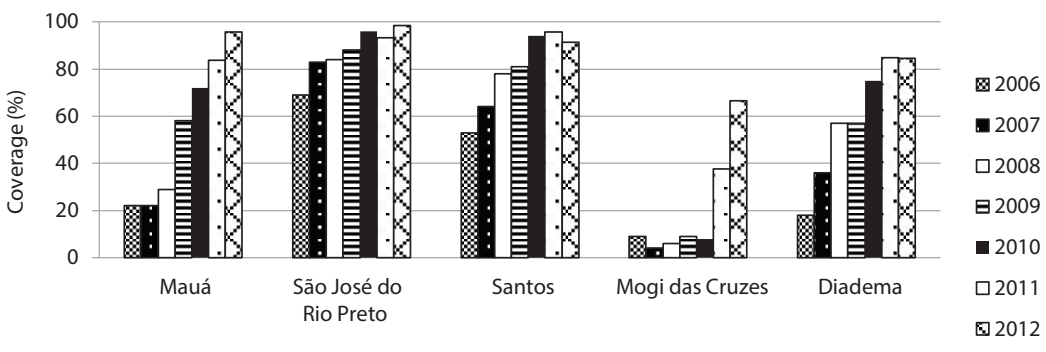

Priority municipalities with a population between 401 and 500 thousand people

Figure 4 - Evolution of Directly Observed Treatment Short-Course coverage in subgroup D from 2006 to 2012, state of São Paulo, Brazil

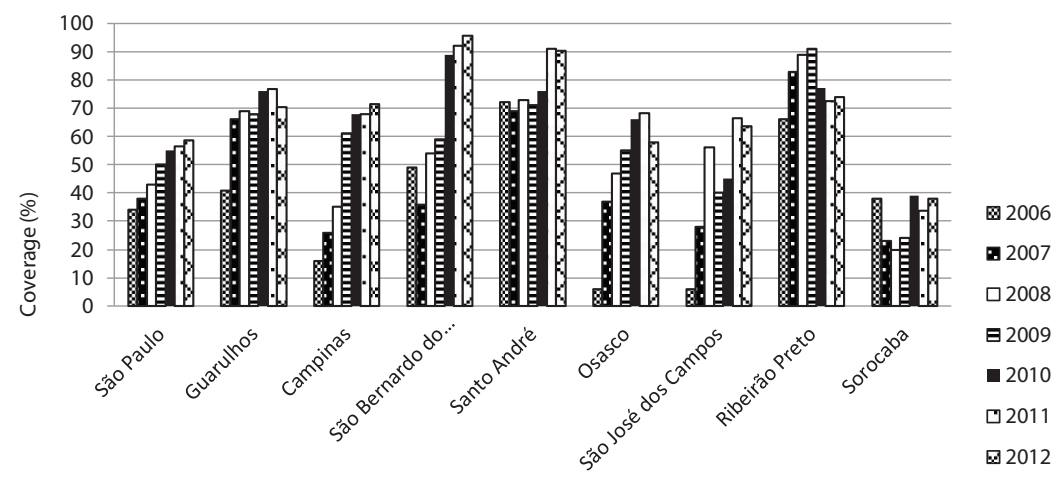

Priority municipalities with a population over 501 thousand people

Figure 5 - Evolution of Directly Observed Treatment Short-Course coverage in subgroup E from 2006 to 2012, state of São Paulo, Brazil

In the subgroup with the greatest population in the state of São Paulo, there was a variation in the implementation and maintenance of DOT coverage. Sorocaba showed the lowest coverage (37.9\%) and São Bernardo do Campo the highest (95.5\%). Guarulhos had a coverage decrease from $76.7 \%$ in 2011 to $70.5 \%$ in 2012; the same tendency was observed for Santo André (from 91.0\% in 2011 to $90.3 \%$ in 2012), Osasco (from 68.1\% in 2011 to 58.1\% in 2012) and São José largest Brazilian city, the DOT coverage has been increasing since 2006. It grew from $34.0 \%$ to $58.5 \%$ in the examined period, with an verage of $47.80 \pm 9.61 \%$. The average coverage for these nine cities $56.7 \%$ (2012), with a standard deviation of $\pm 6.87 \%$ (Figure 5 ).

averages of DOT coverage in subgroups $A, B, C, D$, and $E$ were $.5 \%, 60.5 \%$ and $59.3 \%$, respectively, which means an amplitude of $6.8 \%$. Despite similar averages, the standard deviation values were more heterogeneous: $\pm 6.87, \pm 8.10, \pm 17.7, \pm 11.7$ and \pm 12.0 , respectively, with an amplitude of 10.8 .

\section{DISCUSSION}

The Brazilian Program for Tuberculosis Control actions began to be administrated by municipalities in 2001 and favored primary health care units (Health Family Program and Basic Health Units, or PSF and UBS, as per their acronyms in Portuguese $)^{(4,14)}$. The Local Health Plan of the state of São Paulo, subject to the Ministry of Health through PLANEJASUS establishes goals to be met. One of them is the ratio of TB treatment dropping out as one of the agreed ${ }^{(18-21)}$ and supported indicators in the Management Agreement for the Unified Health System - SUS, which comes through strengthening the capacity to respond to endemics ${ }^{(14,22)}$.

The results reported in the study by Villa et al. (2008), which evaluated 36 priority municipalities for TB control in the state of São Paulo from 1998 to 2004, already indicated that, overall, DOT coverage was increasing in most municipalities, although some of them revealed oscillations, and that DOT coverage was not related to municipality size ${ }^{(6)}$.

Using the same approach and expanding the number of priority municipalities, the present study investigated 59 cities in the state of São Paulo and continues that analysis by examining the period from 2006 to 2012 . The findings showed that the DOT coverage grew in 34 cities (57.6\%) but decreased in 25 (42.4\%). This drop in the maintenance of DOT coverage can be explained by political and management issues, reduction of funding for health actions, discontinuity of management or coordination positions in the Brazilian Program for Tuberculosis Control or the accumulation of several coordination duties from different programs or services as a consequence of the decentralization of TB control actions toward primary care ${ }^{(6,17)}$.

The data showed no correlation between DOT coverage and population size. For instance, São Bernardo do Campo presented a high DOT coverage, $95.5 \%$, in 2012. In contrast, Osasco and 
Sorocaba had coverages of $58.1 \%$ and $37.9 \%$, respectively, suggesting that these cities have different difficulties that resulted in a lower coverage. One of the possible explanations for that is related to the organization of the health system regarding TB surveillance and monitoring of new cases.

Another possible reason for these disparities stands on the assumption that the largest the municipality, the more complex its health system tends to be. However, larger cities have a higher capacity to complement resources from state and federal transfer funds to the health field and to have autonomy to manage the municipal health system ${ }^{(14)}$, which creates a new hypothesis on the priority use of part of the resources for TB control through specific budget allocation and municipal organic laws oriented to this purpose.

The hypothesis presented in other studies ${ }^{(1,3,13,20-21)}$ that the DOT coverage would be related to population size and the inherent complexity of the health system was not confirmed in the present investigation, given that the results show that coverage varied among municipalities with similar population sizes and was heterogeneous even within each subgroup. There were cities with comparable population sizes and different DOT coverages or unrelated population sizes and similar coverage progression. This coverage heterogeneity has to be studied more deeply by exploring the context of the investigated places regarding the political, economic and social situation that influences DOT sustainability in municipalities to control TB.

\section{Study limitations}

The main limitation of the present study was the fact that it focuses on $80.8 \%$ of the priority municipalities of the state of São Paulo only. The authors recommend that new investigations be carried out with all the priority municipalities in the state, regardless of the population size, and also in other Brazilian states, so it is possible to know better the national evolution of DOT coverage.

\section{Contributions to the nursing, health or public policy fields}

As for the nursing field, it is noteworthy the use of quantitative information so there is equity in actions that can promote a better TB control toward the WHO and the Brazilian Program for Tuberculosis Control goals, help state and municipal managers to administer public human and financial resources and assist the federal government to watch the progress of states to combat TB.

\section{CONCLUSION}

The present study evaluated data from 59 municipalities in the state of São Paulo and revealed that the DOT coverage grew in 34 municipalities (57.6\%) and diminished in 25 (42.4\%). This decrease in DOT coverage may result from political and management problems, reduction of funding intended to promote health actions and discontinuity of management or coordination positions in the Brazilian Program for Tuberculosis Control or the accumulation of several coordination duties from different programs or services as a consequence of the decentralization of TB control actions toward primary care ${ }^{(6,17,23)}$.

The authors expect that the findings about the TB situation in the state of São Paulo can provide a basis for local managers to formulate public policies grounded on quantitative data and that help control the disease more effectively, guaranteeing the sustainability of these health actions and the improvement of services oriented to assist people with TB.

\section{FUNDING}

This study received financial support from the Brazilian Postdoctoral Program from the Coordination for the Improvement of Higher Education Personnel (CAPES), reserved to the graduate course in Public Health Nursing from the Ribeirão Preto College of Nursing at University of São Paulo.

\section{REFERENCES}

1. Kritski AL, Ruffino-Netto A, Trajman A, Villa TCS, Silva JRL, Hadad D, et al. Rede Brasileira de Pesquisa em Tuberculose- Rede TB. An Instit Hig Med Trop[Internet]. 2016[cited 2017 Sep 19] 15:535-44. Available from: Available from: http://redetb.org/index. php/234-rede-brasileira-de-pesquisa-em-tuberculose-rede-tb

2. Ministério da Saúde (BR). Secretaria de Vigilância em Saúde. Programa Nacional de Controle da Tuberculose. Manual de Recomendações para o Controle da Tuberculose no Brasil. 2011.

3. Ruffino-Netto A. Tuberculose: a calamidade negligenciada. Rev Soc Bras Med Trop. 2002;35(1):51-8. doi: http://dx.doi.org/10.1590/ S0037-86822002000100010

4. Ministério da Saúde (BR). Fundação Nacional de Saúde. Centro Nacional de Epidemiologia. Coordenação Nacional de Pneumologia Sanitária. Programa de Controle da Tuberculose. Diretrizes do plano de ação emergencial para municípios prioritários. Brasília: MS; 1997.

5. World Health Organization-WHO. Adherence to long-term therapies: Policy for Action[Internet]. Geneva: World Health Organization; 2001 [cited 2015 Sep 19]. Available from: http://www.who.int/chp/knowledge/publications/adherencerep.pdf

6. Villa TCS, Assis EG, Oliveira MF, Arcêncio RA, Gonzales RIC, Palha PF. Cobertura do Tratamento Diretamente Observado (DOTS) da Tuberculose no Estado de São Paulo (1998 a 2004), Brasil. Rev Esc Enferm USP. 2008; 42(1):98-104. doi: http://dx.doi.org/10.1590/ S0080-62342008000100013

7. Ministério da Saúde (BR). Secretaria de Vigilância em Saúde. Departamento de Vigilância Epidemiológica. Coordenação geral de Doenças Endêmicas. Área Técnica de Pneumologia Sanitária. Programa Nacional de Controle da Tuberculose. Brasília; 2004.

8. Instituto Brasileiro de Geografia Estatística-IBGE (BR). Cidades: o Brasil município por município[Internet]. Brasília: Instituto Brasileiro de Geografia Estatística; 2010 [cited 2015 mar 14]. Available from: http://www.ibge.gov.br/home/estatistica/populacao/censo2010/default.shtm 
9. Instituto Brasileiro de Geografia e Estatística-IBGE (BR). Projeção da população do Brasil[Internet]. Brasília: Instituto Brasileiro de Geografia Estatística; 2014[cited 2015 Apr 12]. Available from: http://www.ibge.gov.br/home/estatistica/populacao/estimativa2014/default.shtm

10. Ministério da Saúde (BR). DATASUS. Sistema de Informação de Agravos de Notificação[Internet]. Brasília: Departamento de Informática do SUS; 2014[cited 2015 Apr 08]. Available from: http://datasus.saude.gov.br/

11. World Health Organization-WHO. Global tuberculosis control: surveillance, planning, financing[Internet]. Geneva: World Health Organization; 2010[cited 2015 Jan 18]. Available from: https://books.google.com.br/books?isbn.

12. World Health Organization-WHO. Global tuberculosis report 2014[Internet]. Geneva: World Health Organization; 2014 [cited 2015 Apr 27]. Available from: http://www.who.int/tb/publications/global_report/en/

13. Murray M, Oxlade O, Lin HH. Modeling social, environmental and biological determinants of tuberculosis. Int J Tuberc Lung Dis. 2011;15(Suppl 2):64-70. doi: https://dx.doi.org/10.5588/ijtld.10.0535

14. Ministério da Saúde (BR). Portaria n 373, de 27 de fevereiro de 2002. Norma Operacional da Assistência à Saúde - NOAS SUS 01/2002. Diário Oficial da República Federativa do Brasil, Brasília (DF), 2002 fev 28; Seção 1:52.

15. Sanchez RM, Ciconelli RM. Conceitos de acesso à saúde, Brasil. Rev Panam Salud Publica[Internet]. 2012[cited 2015 Apr 08];31(3):260-8. Available from: https://www.scielosp.org/article/rpsp/2012.v31n3/260-268/

16. Coeli CM. Sistemas de Informação em Saúde e uso de dados secundários na pesquisa e avaliação em saúde, Brasil. Cad Saúde Colet[Internet]. 2010[cited 2015 Apr 08];18(3):335-6. Available from: http://www.cadernos.iesc.ufrj.br/cadernos/images/csc/2010_3/artigos/ CSCv18n3_pag335-6.pdf

17. Beraldo AA, Arakawa T, Pinto ESG, Andrade RLP, Wysocki AD, Silva-Sobrinho RA, et al. Atraso na busca por serviço de saúde para o diagnóstico da tuberculose em Ribeirão Preto (SP), Brasil. Ciênc Saúde Coletiva. 2012;17(11):3079-86. doi: https://dx.doi.org/10.1590/ S1413-81232012001100024

18. Oliveira MF, Arcênio RA, Ruffino-Netto A, Scatena LM, Palha PF, Villa TCS. A porta de entrada para o diagnostico da tuberculose no Sistema de Saúde de Ribeirão Preto/SP. Rev Esc Enferm USP. 2011;45(4):898-904. doi: https://dx.doi.org/10.1590/S0080-62342011000400015

19. Ministério da Saúde (BR). Organização Pan Americana de Saúde-OPAS. Desenvolvimento de Sistemas de Serviços de Saúde. Validação de uma metodologia de avaliação rápida das características organizacionais e do desempenho dos serviços de atenção básica do Sistema Único de Saúde (SUS) em nível local. Brasília; 2006.

20. Yamamura M, Santos Neto M, Freitas IM, Rodrigues LBB, Popolin MP, Uchoa SAC, et al. Tuberculose e iniquidade social em saúde: uma análise ecológica utilizando técnicas estatísticas multivariadas, São Paulo, Brasil. Rev Panam Salud Publica[Internet]. 2014[cited 2015 Feb 7];35(4):270-7. Available from: https://www.scielosp.org/article/rpsp/2014.v35n4/270-277/

21. Muniz JN, Villa TCS, Monroe AA, Hino P. Construindo e organizando a prática do Tratamento Supervisionado no controle da Tuberculose. Espaço Saúde[Internet]. 2001[cited 2015 Feb 7];2(2):16 p. Available from: http://www.ccs.uel.br/espaço para saude/v2n2/doc/tuberculose

22. Governo do Brasil. Poder Executivo. SUS começa a oferecer teste rápido para tuberculose[Internet]. Brasília: Portal Brasil; 2015 [cited 2015 Mar 23]. Available from: http://www.brasil.gov.br/noticias/saude/2014/03/sus-comeca-a-oferecer-teste-rapido-para-tuberculose

23. Ministério da Saúde (BR). Secretaria das Políticas de Saúde. Departamento de Atenção Básica. Coordenação Nacional de Pneumologia Sanitária. Plano de Controle da Tuberculose no Brasil no período de 2007-2015. Brasília; 2006. 